\title{
ANTI-TYROSINASE ACTIVITY FROM VARIOUS SOLVENTS OF PEANUT SHELL (ARACHIS HYPOGAEA L.) EXTRACTS IN VITRO
}

\author{
RISHA FILLAH FITHRIA ${ }^{1 *}$, MELLA DWI KRISDIANA ${ }^{1}$, ETIKA MUSLIMAH ${ }^{1}$, SARIF MUSYAFA $^{1}$, \\ NINING SUGIHARTINI ${ }^{2}$
}

\begin{abstract}
${ }^{1}$ Department of Pharmacology and Clinical Pharmacy, Faculty of Pharmacy, Universitas Wahid Hasyim, Semarang, Indonesia. ${ }^{2}$ Department of Pharmaceutical Technology, Faculty of Pharmacy, Universitas Ahmad Dahlan, Yogyakarta, Indonesia. Email: rishafithria@yahoo.com
\end{abstract}

Received: 15 December 2018, Revised and Accepted: 19 January 2019

ABSTRACT

Objective: This study aimed to determine in vitro anti-tyrosinase activity from various solvents of peanut shell extracts and to find out if the activity is better than kojic acid which is a conventional compound used as anti-hyperpigmentation agent.

Methods: Extraction was done by maceration method with various solvents of ethyl acetate, n-hexane, and $70 \%$ ethanol. Extracts were made into the series concentration of 25,50 , and $75 \mu \mathrm{g} / \mathrm{ml}$. Kojic acid with concentration of $50 \mu \mathrm{g} / \mathrm{ml}$ used as positive control and $5 \%$ dimethyl sulfoxide used as negative control. Tyrosinase enzyme will react with L-3,4-dihydroxyphenylalanine substrate to produce dopachrome compound. The absorbance of dopachrome read by microplate reader at $\lambda=492 \mathrm{~nm}$. If the absorbance read by the microplate reader is low, means that the inhibition power of the peanut shell extract against the tyrosinase enzyme is high. Anti-tyrosinase activity seen by the percentage inhibition value. The percentage inhibition value was analyzed with Kruskal-Wallis test followed by Mann-Whitney U-test; all tests were carried out with a confidence level of 95\%.

Results: The mean of percentage inhibition value of n-hexane extract ranged from $12.44 \pm 1.66 \%$ to $39.82 \pm 1.33 \%$, $70 \%$ of ethanol extract ranged from $39.98 \pm 0.85 \%$ to $70.19 \pm 1.98 \%$, and ethyl acetate extract ranged from $17.85 \pm 0.78 \%$ to $60.30 \pm 0.97 \%$. Kojic acid has mean percentage inhibition value of $78.19 \pm 1.97 \%$. IC ${ }_{50}$ of ethanol, ethyl acetate, and n-hexane extracts was, respectively, $40.53 \mu \mathrm{g} / \mathrm{ml}, 63.49 \mu \mathrm{g} / \mathrm{ml}$, and $91.95 \mu \mathrm{g} / \mathrm{ml}$. Ethanol extract contains flavonoid, tannin, and saponin. Ethyl acetate extract contains flavonoid.

Conclusion: All various solvents of peanut shell extracts have anti-tyrosinase activity but not better than kojic acid. Ethanol extract with concentration of $75 \mu \mathrm{g} / \mathrm{ml}$ has the greatest anti-tyrosinase activity.

Keywords: Peanut shell, Tyrosinase enzyme, Anti-tyrosinase, Anti-hyperpigmentation.

(C) 2019 The Authors. Published by Innovare Academic Sciences Pvt Ltd. This is an open access article under the CC BY license (http://creativecommons. org/licenses/by/4. 0/) DOI: http://dx.doi.org/10.22159/ijap.2019.v11s5.T1007

\section{INTRODUCTION}

Hyperpigmentation is still a serious problem for Indonesian women. There are many things that trigger hyperpigmentation, including exposure to ultraviolet (UV) light, can make the tyrosinase enzyme overwork to convert L-3,4-dihydroxyphenylalanine (L-DOPA) to dopachrome, which eventually turns into melanin [1].

During this time, hyperpigmentation in Indonesia is overcome using kojic acid or hydroquinone as tyrosinase inhibitors, but kojic acid has side effects including allergies and irritation [2,3], while hydroquinone has side effects including irritation and ochronosis [4]. Kojic acid can be used at a concentration of $1 \%-4 \%$ singly or in combination with other agents. Kojic acid when used alone is less effective than hydroquinone $2 \%$ [1].

Natural ingredients that have the potential to be further developed as antihyperpigmentation are peanut shells. Peanut shells are products of peanut crop and ones generally disposed of as waste, but it actually contains high antioxidants potential with total polyphenols, flavonoids, contents of amino acids, alkaloids, and terpenes $[5,6]$. Some previous studies have proven the ability of flavonoids and alkaloids as anti-tyrosinase [7,8]. In this study, we used a variety of solvents to attract various active compounds contained in peanut shells to assess the anti-tyrosinase activity.

\section{MATERIALS AND METHODS}

Materials

Peanut plants were obtained from the village of Sumowono, Semarang, Indonesia. Peanut shells were taken from 3-month-old peanut plants.
$\mathrm{N}$-hexane solvent (technical grade), dimethyl sulfoxide (DMSO) solvent, $\mathrm{pH} 6.8$ phosphate buffer made from $\mathrm{KH} 2 \mathrm{PO} 4$ and $\mathrm{NaOH}$, ethyl acetate solvent, and $70 \%$ ethanol solvent were obtained from PT. Brataco, Indonesia. Tyrosinase enzyme, kojic acid, and levodopa or L-DOPA were obtained from Sigma-Aldrich. Dragendorff reagent made from $\mathrm{Bi}\left(\mathrm{NO}_{3}\right)_{3} \cdot \mathrm{H}_{2} \mathrm{O}, \mathrm{HNO}_{3}$, and $\mathrm{KI}$; Mayer reagent made from $\mathrm{HgCl}_{2}$ and $\mathrm{KI} ; \mathrm{HCl}$ $1 \%$; $\mathrm{NaCl} 2 \%$; $\mathrm{FeCl}_{3} 2 \%$; $\mathrm{NaOH}$; and gelatin $1 \%$ were obtained from PT. Brataco, Indonesia.

\section{Peanut shells extraction}

Twelve kilograms of peanuts were separated from the outer skin. Furthermore, the peanut seeds were cleaned with a cloth, then dried in an oven at a temperature of $40^{\circ} \mathrm{C}$ for approximately $15 \mathrm{~min}$ until completely dry which is indicated by the peanut shells crushed when squeezed by hand. From that process, we obtained $300 \mathrm{~g}$ of peanut shell. The dry peanut shells were pollinated using a blender and measured the water content with a moisture balance tool. Dry water simplicia requirements are $<10 \%$ [9]. One hundred grams of simplicia was macerated using $750 \mathrm{ml}$ of $70 \%$ ethanol for 5 days followed by $250 \mathrm{ml}$ of $70 \%$ ethanol for 2 days. The same thing was done also using n-hexane and ethyl acetate solvents. Liquid extract was concentrated using a rotary evaporator to obtain a thick extract. Yield of 70\% ethanol, ethyl acetate, and n-hexane extracts was obtained, respectively, $15.47 \%, 6 \%$, and $6.09 \%$.

\section{The phytochemical screening test}

Alkaloid test

Two grams of extract were heated in a large test tube with $1 \%$ hydrochloric acid for $30 \mathrm{~min}$ in a boiling water bath. The suspension 
is filtered into the test tube A and B as much. Test tube A added three drops of Dragendorff reagent and test tube B added three drops of Mayer reagent.

\section{Tannin test}

Fifty milligrams of extract is heated with $10 \mathrm{ml}$ of water for 30 min over a water bath. Then filtered, filtrate plus $1 \mathrm{ml}$ of $\mathrm{NaCl} \%$ solution. If deposits are formed, then filtered. The filtrate is added $2 \mathrm{ml}$ of $1 \%$ gelatin.

\section{Saponin test}

Add the aquadest to the test tube containing 100 mg extract, cover, and shake vigorously for $30 \mathrm{~s}$. Leave the tube in an upright position for $30 \mathrm{~min}$.

\section{Flavonoid and phenolic compound tes}

Five milligrams of extract was dissolved in $2 \mathrm{ml}$ of $96 \%$ ethanol and then divided into two test tubes. Test tube A added three drops of $2 \%$ $\mathrm{FeCl}_{3}$ solution and test tube $\mathrm{B}$ added three drops of $0.2 \mathrm{~N} \mathrm{NaOH}$ solution.

\section{The anti-tyrosinase activity test}

This test adopts a method from Masuda et al. [10]. First, prepared 8 wells consisting of A group (consists of 3 wells), B group (consists of 1 well), C group (consists of 3 wells), and D group (consists of 1 well). A group consists of $120 \mu \mathrm{L}$ of pH 6.8 phosphate buffer and $40 \mu \mathrm{L}$ of tyrosinase enzyme (496 units $/ \mathrm{mL}$ ). B group consists of $160 \mu \mathrm{L}$ of pH 6.8 phosphate buffer. $\mathrm{C}$ group consists of $80 \mu \mathrm{L}$ of $\mathrm{pH} 6.8$ phosphate buffer, $40 \mu \mathrm{L}$ of 496 units/mL tyrosinase enzyme, and $40 \mu \mathrm{L}$ of tested group. D group consists of $120 \mu \mathrm{L}$ of pH 6.8 phosphate buffer and $40 \mu \mathrm{L}$ of tested group. Each mixture was incubated at $25^{\circ} \mathrm{C}$ for $10 \mathrm{~min}$. Furthermore, each mixture was added $40 \mu \mathrm{L}$ of $2.5 \mathrm{mM} \mathrm{L}$-DOPA then incubated at a temperature of $25^{\circ} \mathrm{C}$ for $10 \mathrm{~min}$. Furthermore, the mixture is measured using a microplate reader at a wavelength of $492 \mathrm{~nm}$. Anti-tyrosinase activity is seen by the percentage inhibition value, which is calculated using the following formula:

$$
\frac{([A-B]-[C-D])}{(A-B)} \times 100 \%
$$

Where, $(A)$ : The absorbance of negative blank solution with tyrosinase enzyme; $(B)$ : The absorbance of negative blank solution without tyrosinase enzyme; $(C)$ : The absorbance of tested group solution with tyrosinase enzyme; and $(D)$ : The absorbance of tested group solution without tyrosinase enzyme.

The percentage inhibition data then were tested for normality using the Shapiro-Wilk test and tested for homogeneity using Levene's test, then tested using one-way ANOVA and least significant difference tests at $95 \%$ confidence level.

\section{RESULTS AND DISCUSSION}

The formation of dopachrome products is characterized by the appearance of the brown color produced by the reaction between L-DOPA and the tyrosinase enzyme. The brown color intensity will determine the dopachrome compound that is formed, meaning that the higher the intensity of the brown color, the more dopachrome compounds will be produced. If tyrosinase is inhibited, the formation of dopachrome will also be inhibited. The higher the inhibition of an inhibitor, the lower the intensity of the brown color [11]

After obtaining the percentage inhibition value (Table 1) from the dopachrome absorbance data, then the normal data distribution was analyzed using the Shapiro-Wilk test and the homogeneity was analyzed using Levene's test, produced homogenous data ( $p>0.05$ ) but anomaly distributed data $(\mathrm{p}<0.05)$ so that it was tested using KruskalWallis test followed by Mann-Whitney U-test; all tests were carried out with a confidence level of $95 \%$. The mean of percentage inhibition value of $n$-hexane extracts ranged from $12.44 \pm 1.66 \%$ to $39.82 \pm 1.33 \%, 70 \%$ ethanol extracts ranged from $39.98 \pm 0.85 \%$ to $70.19 \pm 1.98 \%$, and ethyl acetate extracts ranged from $17.85 \pm 0.78 \%$ to $60.30 \pm 0.97 \%$. Kojic acid has mean percentage inhibition value of $78.19 \pm 1.97 \%$.

All various solvents of peanut shell extract and kojic acid have greater and different meaningful inhibition percentage value than the negative control DMSO (p.0.00). This indicates that peanut shell extracts and kojic acid have antityrosinase activity. Kojic acid has inhibition percentage value that higher than all various solvents of peanut shell extract (p.0.00). The higher the concentration of extract, the higher the percentage inhibition value (p.0.00). Ethanol extract with concentration of $75 \mu \mathrm{g} / \mathrm{ml}$ has the greatest anti-tyrosinase activity $\left(\mathrm{IC}_{50}: 40.53 \mu \mathrm{g} / \mathrm{ml}\right.$ ) among the whole extracts (ethyl acetate extract has $\mathrm{IC}_{50}$ value of $63.49 \mu \mathrm{g} / \mathrm{ml}$ and $\mathrm{n}$-hexane extract has $\mathrm{IC}_{50}$ value of $91.95 \mu \mathrm{g} / \mathrm{ml}$ ). This is thought to be due to the presence of phenolic compounds in ethanol extract.

The phytochemical screening test resulted that ethanol extract of peanut shell contains flavonoid, tannin, and saponin (Fig. 1); the ethyl acetate extract of peanut shell contains flavonoid (Fig. 2), while the results in n-hexane extract were negative. The addition of gelatin to the extract filtrate produces yellow deposits which indicated that the extract contains tannin compounds. The formation of foam which lasted for $30 \mathrm{~min}$ in the extract solution after strong shaking showed the presence of saponin compounds in the extract. The formation of yellow deposits after addition of $\mathrm{NaOH}$ to the mixture of extracts and $96 \%$ ethanol indicating the presence of flavonoids in the extract. The

Table 1: Percentage inhibition value

\begin{tabular}{ll}
\hline Groups & Percentage inhibition value (\%) \\
\hline N-hexane extract $25 \mu \mathrm{g} / \mathrm{ml}$ & $12.44 \pm 1.66$ \\
$\mathrm{~N}$-hexane extract $50 \mu \mathrm{g} / \mathrm{ml}$ & $28.82 \pm 1.33$ \\
$\mathrm{~N}-$ hexane extract $75 \mu \mathrm{g} / \mathrm{ml}$ & $39.82 \pm 2.32$ \\
Ethyl acetate extract $25 \mu \mathrm{g} / \mathrm{ml}$ & $17.85 \pm 0.78$ \\
Ethyl acetate extract $50 \mu \mathrm{g} / \mathrm{ml}$ & $37.47 \pm 2.03$ \\
Ethyl acetate extract $75 \mu \mathrm{g} / \mathrm{ml}$ & $60.30 \pm 0.97$ \\
$70 \%$ ethanol extract $25 \mu \mathrm{g} / \mathrm{ml}$ & $39.98 \pm 0.85$ \\
$70 \%$ ethanol extract $50 \mu \mathrm{g} / \mathrm{ml}$ & $56.86 \pm 1.96$ \\
$70 \%$ ethanol extract $75 \mu \mathrm{g} / \mathrm{ml}$ & $70.19 \pm 1.98$ \\
Kojic acid $50 \mu \mathrm{g} / \mathrm{ml}$ & $78.19 \pm 1.97$ \\
DMSO & $-18.5 \pm 3.82$ \\
\hline
\end{tabular}

${ }^{a}$ Mean \pm SE, $n=3$. DMSO: Dimethyl sulfoxide, SE: Standard error

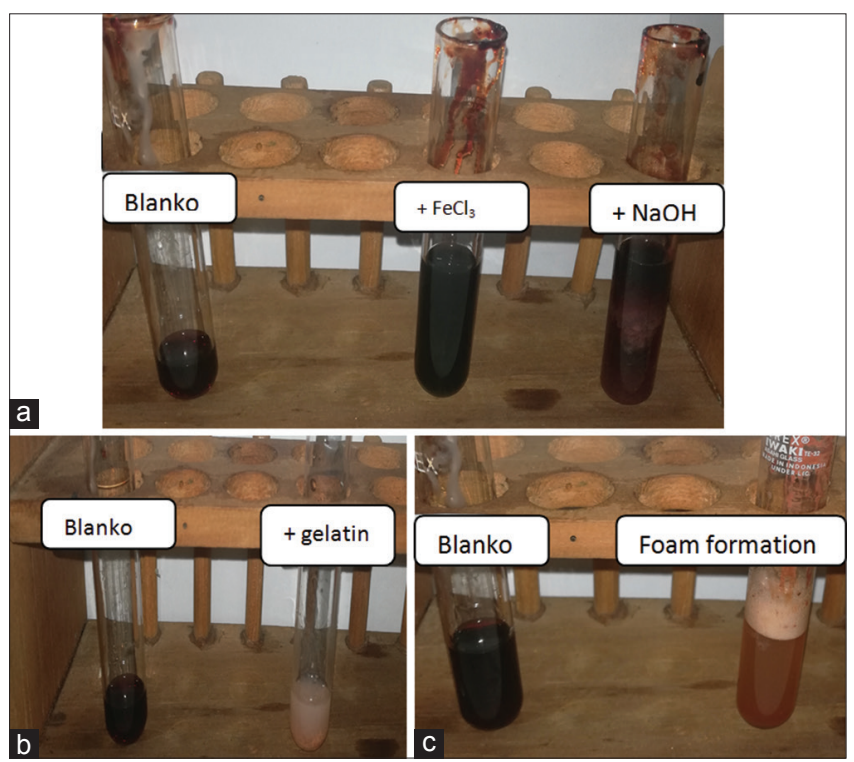

Fig. 1: The phytochemical screening of the ethanol extract of peanut shell, (a) flavonoid and phenolic compound test, (b) tannin test, (c) saponin test 


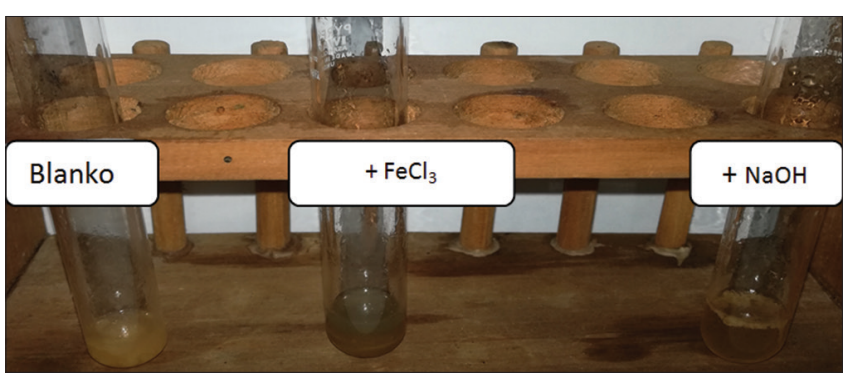

Fig. 2: The flavonoid and phenolic compound test of ethyl acetate extract of peanut shell

formation of blue-green color after adding $\mathrm{FeCl}_{3}$ to the mixture of extract and $96 \%$ ethanol showed the presence of phenolic compounds in the extract.

Flavonoid, tannin, and saponin are phenolic compounds. Several studies have proven the existence of phenolic compound in peanut shells. Dean et al. identified $425 \pm 33 \mathrm{mg} \mathrm{FA} / 100 \mathrm{~g}$ phenolic compounds in acetone extract of peanut shell [12]. Adhikari et al. identified $142 \mathrm{mg}$ of flavonoid compound on methanol extract [5]. Win et al. identified that phenolic composition of peanut shell is p-hydroxybenzoic acid, resveratrol, and luteolin [6].

Phenolic compounds have been proven through several studies regarding their activity in inhibiting tyrosinase. Alam et al. have carried out research on the anti-tyrosinase effect of Pleurotus ferulae, which has an effect of $19.81 \%-60.10 \%$. The extract contains 11 phenolic compounds and gallic acid is the largest content of $40 \mu \mathrm{g} / \mathrm{g}$ [13]. Corradi et al. investigated that gallic acid was found to be the key compound related to the tyrosinase activity detected in Schinus terebinthifolius extracts [14]. The inhibition of tyrosinase effect might be due to the hydroxyl groups of the phenolic compounds that could form a hydrogen bond at the active site of the enzyme, leading to a lower enzymatic activity [15].

Thisstudy will be continued to examine the ex vivo anti-hyperpigmentation activity of peanut shell ethanol extract on guinea pigs, which were previously irradiated with $311 \mathrm{~nm}$ UV-B light to make black spots on guinea pig skin. If proven to have anti-hyperpigmentation effect, it will be continued to be formulated and retested to obtain an extract formula which is optimal as an anti-hyperpigmentation.

\section{CONCLUSION}

All various solvents of peanut shell extracts have anti-tyrosinase activity $(p<0.05)$ but not better than kojic acid. Ethanol extract of peanut shell with concentration of $75 \mu \mathrm{g} / \mathrm{ml}$ has the greatest anti-tyrosinase activity and the smallest $\mathrm{IC}_{50}$ among the whole extracts. This effect is thought to be due to the presence of phenolic compounds in ethanol extract of peanut shell. Thus, the study clearly indicated a promising tyrosinase inhibition potential of peanut shell, the by-product of peanut crop. This research really needs to be continued through a series of tests to test the ability of phenolic compounds in peanut shell extract to overcome hyperpigmentation.

\section{CONFLICTS OF INTEREST}

All authors have none the conflicts of interest.

\section{ACKNOWLEDGMENT}

We would like to thank the overseas seminar assistance program, Directorate General of Strengthening Research and Development, the Ministry of Technology Research and Higher Education of the Republic of Indonesia, for the support to the authors in presenting our research on ICPPS 2019.

\section{REFERENCES}

1. Fithria RF, Anas Y, Safitri EI. Antihyperpigmentation effect of the combination of turmeric (Curcuma domestica Val.) and bitter melon leaves (Momordica charantia L.) ethanol extracts on guinea pig skin. J Kefarmasian Ind 2018;8:10-6.

2. Nakagawa M, Kawai K, Kawai K. Contact allergy to kojic acid in skin care products. Contact Dermatitis 1995;32:9-13.

3. Saghaie L, Pourfarzam M, Fassihi A, Sartippour B. Synthesis and tyrosinase inhibitory properties of some novel derivatives of kojic acid. Res Pharm Sci 2013;8:233-42.

4. Sarkar R, Arora P, Garg KV. Cosmeceuticals for hyperpigmentation: What is available? J Cutan Aesthet Surg 2013;6:4-11.

5. Adhikari B, Dhungana SK, Ali MW, Adhikari A, Kim D, Shin DH. Antioxidant activities, polyphenol, flavonoid, and amino acid contents in peanut shell. J Saudi Soc Agric Sci 2018;2:1-5.

6. Win MM, Hamid AA, Baharin S, Anwar F, Sabu MC, Pak-Dek MS. Phenolic compounds and antioxidant activity of peanut's skin, hull, raw kernel and roasted kernel flour. Pak J Bot 2011;43:1635-42.

7. Morikawa $\mathrm{T}$, Kitagawa N, Tanabe G, Ninomiya $\mathrm{K}$, Okugawa $\mathrm{S}$, Motai C, et al. Quantitative determination of alkaloid in lotus flower (Flower Buds of Nelumbo nucifera) and their melanogenesis inhibitory activity. Molecules MDPI 2016;21:930.

8. Matsuda H, Masuda M, Murata K, Abe Y, Uwaya A. Study of the antiphotoaging effect of noni (Morinda citifolia). In: Duc GH, editor. Melanoma - From Early Detection to Treatment. Vol. 23. Croatia: Intech; 2013. p. 629-48.

9. BPOM RI. Traditional Medicine Quality Requirement. National Agency of Drug and Food Control (BPOM); 2014.

10. Masuda T, Yamashita D, Takeda Y, Yonemori S. Screening for tyrosinase inhibitors among extracts of seashore plants and identification of potent inhibitors from Garcinia subelliptica. Biosci Biotechnol Biochem 2005;69:197-201.

11. Kartika Y. Screening of Zingiberaceae Family Leaf Extracts as Tyrosinase Inhibitors and Antioxidant. Essay. Bogor: Chemistry Department, Faculty of Math and Science, Institut Pertanian Bogor; 2015.

12. Dean LL, Davis JP, Shofran BG, Sanders TH. Phenolic profiles and antioxidant activity of extracts from peanut plant parts. Open Natl Prod J 2008;1:1-6.

13. Alam N, Yoon KN, Lee JS, Cho HJ, Lee TS. Consequence of the antioxidant activities and tyrosinase inhibitory effects of various extracts from the fruiting bodies of pleurotus ferulae. Saudi J Biol Sci 2012;19:111-8.

14. Corradi ID, Souza ED, Sande D, Takahashi JA. Correlation between phenolic compounds contents, antityrosinase and antioxidant activities of plant extracts. Chem Eng Trans 2018;64:109-14.

15. Baek HS, Rho HS, Yoo JW, Ahn SM, Lee JY, Lee J, et al. The inhibitory effect of new hydroxamic acid derivatives on melanogenesis. Bull Korean Chem 2008;29:43-6. 